\title{
Veroordeeld tot (g)een baan
}

\section{Hoe delict- en persoonskenmerken arbeidsmarktkansen beïnvloeden ${ }^{*}$}

\author{
Chantal van den Berg, Lieselotte Blommaert, Catrien Bijleveld \& Stijn Ruiter
}

Eerder onderzoek heeft laten zien dat sollicitanten met een veroordeling een kleinere kans hebben op het krijgen van een baan in vergelijking met sollicitanten zonder strafblad. Tegelijkertijd is het voor veroordeelden juist van belang dat zij een baan vinden, aangezien het hebben van werk de kans op recidive aanzienlijk vermindert. Om te onderzoeken in hoeverre het hebben van een strafblad de kansen op de arbeidsmarkt bemoeilijkt, hebben wij 520 motivatiebrieven met cv's verstuurd in reactie op internetvacatures. Alle motivatiebrieven en cv's waren identiek, met dien verstande dat systematisch was gevarieerd op het type delict (geen delict, gewelds-, vermogens- of zedendelict), de termijn tussen veroordeling en sollicitatie, de bedrijfssector en de etniciteit van de sollicitant. De resultaten laten geen verschillen in arbeidsmarktkansen zien naar type delict of geen delict. Wel wordt een sterk effect gevonden voor etnische herkomst. Het is zelfs zo dat etnische minderheden met een blanco strafblad een geringere kans hebben op het ontvangen van een positieve reactie naar aanleiding van een sollicitatie dan een geweldsdelinquent met een Nederlandse achtergrond.

\section{Introductie}

Voor veroordeelden is het hebben van een baan een belangrijke factor voor het voorkomen van verdere delinquentie. Verschillende mechanismen spelen hierbij mogelijk een rol. Zo stelt Becker (1968) dat de financiële inkomsten van legaal werk de behoefte tot inkomsten uit illegale bronnen, zoals criminaliteit, doen verminderen. Het hebben van een baan wordt ook verondersteld een beschermende factor te zijn omdat werkenden minder tijd en gelegenheden zouden hebben voor het plegen van criminaliteit dan werklozen (Osgood e.a., 1996). Verder zouden de sociale banden met collega's en de bij de baan behorende sociale normen en waarden het plegen van criminaliteit minder aantrekkelijk maken (Sampson \& Laub, 1993; Sutherland \& Cressey, 1978). Uit verschillende onderzoeken is dan ook gebleken dat veroordeelden met een baan inderdaad een kleinere kans op recidive hebben (o.a. Crutchfield \& Pitchford, 1997; Mesters e.a., 2015; Sampson \& Laub, 1993; Uggen, 2000; Van der Geest e.a., 2011; Wadsworth, 2006). Wanneer een veroordeelde dus problemen ervaart bij het vinden van een baan, kan dit een succesvolle integratie in de samenleving tegenwerken.

* De auteurs danken Irène Ambachtsheer, Inge de Kruif, Myriam de Lange, Emiel van Renselaar en Jan Wagemaakers voor de dataverzameling bij dit onderzoek. 
Uit de empirische literatuur blijkt dat veroordeelden vaak moeite hebben met het vinden van een baan (o.a. Bushway e.a., 2007). In hoeverre deze moeilijkheden ook daadwerkelijk het gevolg zijn van hun veroordeling blijft onduidelijk. Dit komt door beperkingen in de onderzoeksopzet van veel eerdere onderzoeken naar de relatie tussen delinquentie en arbeidsmarktkansen. Vaak gebruiken deze onderzoeken niet-experimentele methoden, waarbij moeilijk vast te stellen is of de ongunstiger arbeidsmarktkansen van veroordeelden te wijten zijn aan de veroordeling of aan andere kenmerken. Zo kan een detentieperiode leiden tot schoolverlating of baanverlies. De ontwikkeling van kennis, vaardigheden en relevante arbeidsmarktervaring van de veroordeelde stokt dan. Hierdoor worden exgedetineerden minder aantrekkelijk als potentiële werknemer voor werkgevers (Becker, 1964). Daarnaast kunnen mogelijke negatieve stereotypen die werkgevers hebben ten aanzien van veroordeelden de arbeidsmarktkansen van deze groep negatief beïnvloeden (Pager e.a., 2009b). Maar het kan ook zo zijn dat de ongunstige arbeidsmarktkansen niet het gevolg zijn van de detentieperiode of stereotypen, maar van andere kenmerken van de veroordeelden, zoals hun gemiddeld lagere opleidingsniveau of beperktere werkervaring. Het is namelijk bekend dat personen met een lagere sociaaleconomische status en een lager opleidingsniveau een grotere kans hebben op betrokkenheid bij criminaliteit en als gevolg een grotere kans om gedetineerd te worden (Freeman, 1999; Lochner, 2004). Veroordeelden beschikken - mede daardoor - minder vaak over een relevant diploma, kennis, vaardigheden of een stabiele werkgeschiedenis (Uggen, 1999; Uggen e.a., 2005). Dit maakt hen naar alle waarschijnlijkheid een selectieve groep, met minder kansen op de arbeidsmarkt. De meest geschikte manier om dergelijke selectieeffecten uit te sluiten en de causale effecten van justitiecontacten op iemands arbeidsmarktkansen te identificeren, is het gebruik van veldexperimenten.

Een aantal eerdere onderzoeken naar de relatie tussen criminaliteit en arbeidsmarktkansen maakte gebruik van een experimenteel design waarmee causale verbanden kunnen worden aangetoond (Baert \& Verhofstadt, 2013; Boshier \& Johnson, 1979; Buikhuisen \& Dijksterhuis, 1971; Dirkzwager e.a., 2015; Decker e.a., 2014; Deliens, 1983; Galgano, 2009; Pager, 2003; 2007; Pager e.a., 2009a; 2009b; Schwartz \& Skolnick, 1962). In deze experimenten solliciteerden fictieve werkzoekenden met en zonder crimineel verleden naar daadwerkelijk bestaande posities en werden de reacties van werkgevers op deze sollicitaties gemeten. Het overgrote deel van deze onderzoeken heeft aangetoond dat een veroordeling de arbeidsmarktkansen van werkzoekenden verkleint, maar het effect van het hebben van een strafblad verschilde sterk tussen en zelfs binnen studies.

Een mogelijke verklaring voor de gevonden verschillen is gelegen in variaties in de onderzoeksopzet van de eerdere veldexperimenten. Zo verschilden de experimenten wat betreft het type delict en de gepercipieerde ernst van het gepleegde delict, als ook wat betreft de opgelegde sancties. Ook variaties in de verstreken termijn tussen de veroordeling en de sollicitatie spelen mogelijk een rol. Daarnaast verschilden de experimenten wat betreft de etniciteit van de sollicitanten. In sommige studies ging het uitsluitend om autochtone sollicitanten, terwijl in andere studies sollicitanten uit verschillende herkomstgroepen werden meegenomen. Als laatste kunnen ook verschillen tussen arbeidsmarktsectoren van invloed zijn. 
In het huidige onderzoek dragen wij op verschillende manieren bij aan de kennis over de invloed van een veroordeling op de arbeidsmarktkansen van werkzoekenden. Ten eerste onderzoeken we het causale effect van een veroordeling op de arbeidsmarktkansen van werkzoekenden door middel van een veldexperiment waarbij fictieve cv's en motivatiebrieven verstuurd werden naar werkgevers in reactie op online vacatures. Ten tweede is in ons experiment het type delict als ook de lengte van de tijd tussen de veroordeling en de sollicitatie gevarieerd om te onderzoeken in hoeverre deze factoren gezamenlijk en in vergelijking met elkaar de sterkte van het effect van een strafblad op de kansen van sollicitanten beïnvloeden. In tegenstelling tot eerdere onderzoeken zal dit onderzoek zich niet richten op één type delict, maar op drie verschillende soorten (geweldsdelicten, vermogensdelicten en zedendelicten), die verschillen in aard en gepercipieerde ernst. Het hebben gepleegd van een bepaald type delict is mogelijk van invloed op de inschatting van werkgevers over de mate waarin men bepaalde functies kan uitoefenen. Om die reden zijn in het experiment vacatures betrokken uit drie verschillende arbeidsmarktsectoren: bouw, logistiek en techniek. Ten slotte onderzoeken we de invloed van de etniciteit van werkzoekenden op hun arbeidsmarktkansen en gaan we na in hoeverre het effect van een strafblad anders is voor sollicitanten uit verschillende herkomstgroepen.

\section{De invloed van criminaliteit op arbeidskansen}

Verschillende theorieën veronderstellen dat het hebben van een strafblad de kans op een baan negatief beïnvloedt. Volgens economische theorieën, zoals de menselijk-kapitaaltheorie van Becker (1964), zoeken potentiële werkgevers naar de persoon met de vaardigheden en kennis die nodig zijn om de beoogde arbeid te leveren. Delinquentie en de daarmee gepaard gaande afwezigheid op de arbeidsmarkt door bijvoorbeeld detentie, zorgen ervoor dat de benodigde kennis en vaardigheden onvoldoende kunnen worden opgebouwd. Hierdoor wordt het moeilijker een baan te vinden en kan dit, wanneer men lange tijd werkloos is, zelfs leiden tot een verdere afname van kennis en vaardigheden. Het feit dat iemand een delict heeft gepleegd, zal volgens deze theorie dus als iets negatiefs gezien worden door potentiële werkgevers.

De signaleringstheorie van Spence (1973) gaat uit van hetzelfde principe, maar de nadruk ligt in deze theorie meer op de overwegingen van werkgevers. Volgens deze theorie maken werkgevers een afweging aan de hand van signalen en aanwijzingen, zoals opleiding, werkervaring en persoonskenmerken. Een periode van werkloosheid en een strafblad zullen volgens deze theorie gezien worden als negatieve signalen, die kunnen leiden tot een afwijzing van de potentiële werknemer (zie o.a. Buikhuisen \& Dijksterhuis, 1971; Luijkx \& Wolbers, 2009).

Dan zijn er nog de verschillende 'labeling'-theorieën, waarin het label 'delinquent' centraal staat. Dit label wordt geassocieerd met negatieve persoonskenmerken, zoals onbetrouwbaar en agressief gedrag (Holzer e.a., 2004). Vanwege deze associatie zal een potentiële werkgever minder snel geneigd zijn een persoon met een strafblad aan te nemen. Daar komt nog bij dat wanneer een individu zich bewust 
is van zijn label als delinquent, hij ontmoedigd kan raken en mogelijk minder gemotiveerd op zoek zal gaan naar werk.

$\mathrm{Al}$ met al volgt uit bovenstaande theorieën dezelfde conclusie, namelijk dat werkgevers minder snel geneigd zullen zijn ex-delinquenten aan te nemen vanwege de associatie van delinquentie met negatieve kenmerken.

\section{Eerder onderzoek}

Experimentele studies naar de effecten van het hebben van een strafblad op iemands arbeidsmarktkansen zijn zeldzaam. In totaal zijn er wereldwijd elf veldexperimenten bekend waarin werd onderzocht in hoeverre sollicitanten minder vaak positieve reacties van werkgevers - een uitnodiging voor een gesprek of een baanaanbod - kregen als ze bij sollicitaties melding maakten van een vervolging of een veroordeling in hun verleden. In de jaren zestig tot en met de jaren tachtig zijn in vier verschillende landen experimenten uitgevoerd, in de Verenigde Staten, Nederland, Nieuw-Zeeland en België. Telkens werd onderzocht in hoeverre het melden van een vervolging of veroordeling in hun verleden de kansen van sollicitanten bij schriftelijke sollicitaties beïnvloedde (Boshier \& Johnson, 1974; Buikhuisen \& Dijksterhuis, 1969; Deliens, 1983; Schwartz \& Skolnick, 1962). In de eerste twee decennia van deze eeuw zijn in de Verenigde Staten vijf experimenten uitgevoerd waarin de invloed van een veroordeling op de kans op een positieve reactie van een werkgever werd onderzocht. Dit werd onderzocht door middel van sollicitaties op online vacatures of door middel van acteurs die persoonlijk solliciteerden bij potentiële werkgevers (Decker e.a., 2014; Galgano, 2009; Pager, 2003; 2007; Pager e.a., 2009a; 2009b). Ook werden in deze periode twee experimenten uitgevoerd buiten de Verenigde Staten, een in Nederland en een in België, waarbij door middel van het versturen van e-mails naar organisaties die een vacature hadden, werd onderzocht in hoeverre een veroordeling of eerder verblijf in een open jeugdinrichting de kans op het ontvangen van een positieve reactie beïnvloedde (Baert \& Verhofstadt, 2013).

Samen tonen deze experimenten aan dat het hebben van een strafblad of een detentie- of instellingsverleden de kans op een positieve reactie van een werkgever inderdaad kan verlagen. Het effect van het hebben van een strafblad op de arbeidsmarktkansen van sollicitanten blijkt echter sterk te verschillen tussen en zelfs binnen studies; in sommige gevallen werd een sterke invloed van een strafblad gevonden, terwijl het in andere gevallen slechts ging om een klein of zelfs geen statistisch significant effect. Zo vonden Boshier en Johnson (1974) geen effect van een veroordeling wegens rijden onder invloed, maar wel een effect voor een veroordeling wegens diefstal. Deliens (1983) vond alleen een statistisch significant effect van de detentieperiode wanneer gesolliciteerd werd in de productiesector. Verder vonden Decker en collega's (2014) slechts marginaal significante of zelfs niet-significante effecten van een detentieverleden bij online sollicitaties, terwijl wel statistisch significante effecten werden gevonden als een acteur een potentiële werkgever persoonlijk benaderde. Baert en Verhofstadt (2013) vonden een sterker negatief effect wanneer gesolliciteerd werd voor de positie van bar- 
keeper of elektrotechnisch ingenieur dan wanneer er gesolliciteerd werd naar een ander type functie. Ten slotte vonden Dirkzwager en collega's (2015) helemaal geen statistisch significante effecten van een detentieverleden op de kans op een positieve reactie van een werkgever, terwijl zij wel vonden dat ex-gedetineerden een statistisch significant kleinere kans hebben op een positieve reactie wanneer zij op zoek zijn naar een huurwoning.

Al die verschillende uitkomsten roepen de vraag op wat de variatie in de gevonden effecten veroorzaakt. Een mogelijke verklaring kan worden gezocht in de uiteenlopende onderzoeksopzet van de veldexperimenten. De studies verschillen onder andere wat betreft het type delict en de ernst van het delict of de duur van de detentieperiode waarvan sollicitanten in hun sollicitatie melding maakten. In de meeste experimenten in de Verenigde Staten werd melding gemaakt van een veroordeling wegens drugsbezit (Decker e.a., 2014; Pager, 2003; 2007; Pager e.a., 2009a; 2009b). In enkele oudere experimenten in België, Nieuw-Zeeland en Nederland ging het om diefstal (Deliens, 1983) of werd er onderscheid gemaakt tussen rijden onder invloed en diefstal (Boshier \& Johnson, 1974; Buikhuizen \& Dijksterhuis, 1969). Uit de resultaten van bestaande studies komt geen eenduidig beeld naar voren over de invloed van het type delict op de kans dat sollicitanten een positieve reactie krijgen van werkgevers. Hierdoor is de verwachting ook dat er verschillen zijn in hoe bepaalde typen delict de arbeidsmarktkansen beïnvloeden.

Wat ook opvalt, is dat de kansen op een positieve reactie sterk verschillen tussen de afzonderlijke experimenten, zelfs als daarin eenzelfde type delict werd vermeld, zoals bij het merendeel van de recentere studies in de Verenigde Staten het geval is (Decker e.a., 2014; Pager, 2003; 2007; Pager e.a., 2009a; 2009b). In de overige experimenten werd het type delict niet vermeld, maar lag de nadruk op het type en de duur van de strafmaatregel (Baert \& Verhofstadt, 2013; Dirkzwager e.a., 2015; Galgano, 2009; Schwartz \& Skolnick, 1962). Zo varieert de duur van de detentieperiode die sollicitanten vermeldden in hun sollicitatie van een maand (Deliens, 1983) of enkele maanden (Dirkzwager e.a., 2015; Galgano, 2009) tot drie jaar (Decker e.a., 2014). In een groot deel van de experimenten werd echter een detentieduur vermeld van een jaar (Baert \& Verhofstadt, 2013) of anderhalf jaar (Pager, 2003; 2007; Pager e.a., 2009a; 2009b). Hoewel enige voorzichtigheid geboden is bij het trekken van conclusies op basis van een relatief klein aantal niet strikt vergelijkbare veldexperimenten, lijken de resultaten van deze studies samen erop te wijzen dat de kans op een uitnodiging kleiner wordt naarmate een ernstiger delict of een langere straf wordt vermeld. Het experiment waarin de langste detentieperiode - drie jaar - werd vermeld (Decker e.a., 2014), vond het sterkste effect, gevolgd door de experimenten waarin een detentieperiode van anderhalf jaar werd vermeld (Galgano, 2009; Pager, 2003; 2007; Pager e.a., 2009a; 2009b). Decker en collega's (2014) vonden dat voor sollicitanten zonder detentieverleden de kans op een positieve reactie twee keer groter was dan wanneer de sollicitant een detentieverleden had. In de experimenten waarin een detentieperiode werd vermeld van anderhalf jaar, werd gevonden dat sollicitanten zonder detentieverleden tussen 1,3 en 2 keer zo veel kans hadden op een uitnodiging als sollicitanten met een detentieverleden. In experimenten waarin een detentieperi- 
ode van een jaar of minder werd vermeld (Baert \& Verhofstadt, 2013; Deliens, 1983; Dirkzwager e.a., 2015; Galgano, 2009), was het effect relatief klein; sollicitanten zonder detentieverleden hadden 1,2 tot 1,4 keer zo veel kans als sollicitanten met detentieverleden, of er werd geen statistisch significant effect gevonden. Ook werd in sommige experimenten gedetailleerde informatie gegeven over het type straf (Schwartz \& Skolnick, 1962). In het onderzoek van Baert en Verhofstadt (2013) ging het om jeugddetentie, terwijl in het onderzoek van Galgano (2009) werd vermeld dat de straf was uitgezeten in een zwaarbewaakte gevangenis.

Een laatste verschil tussen veldexperimenten is dat sommige - vooral oudere studies zich beperkten tot autochtone sollicitanten, terwijl meer recente studies in de Verenigde Staten (Decker e.a., 2014; Galgano, 2009; Pager, 2003; 2007; Pager e.a., 2009a; 2009b) en in Nederland (Dirkzwager e.a., 2015) tegelijkertijd de invloed onderzochten van het hebben van een strafblad en van de etnische achtergrond van de sollicitant. De resultaten van deze experimenten lieten zien dat ook etnische achtergrond van invloed is op de arbeidsmarktkansen van sollicitanten. Afro-Amerikaanse en Latijns-Amerikaanse sollicitanten en MarokkaansNederlandse en Turks-Nederlandse sollicitanten ontvingen statistisch significant minder vaak positieve reacties van werkgevers dan autochtone of blanke ${ }^{1}$ sollicitanten. Soms ontvingen blanke sollicitanten met een detentieverleden zelfs vaker een positieve reactie dan Afro-Amerikaanse en Latijns-Amerikaanse sollicitanten zonder strafblad (Pager e.a., 2009a; 2009b). Ook experimenten die zich enkel richten op het effect van de etnische achtergrond van sollicitanten (en waarin het al dan niet hebben van een strafblad buiten beschouwing blijft), laten vrijwel zonder uitzondering zien dat de etnische achtergrond van sollicitanten hun arbeidsmarktkansen beïnvloedt (Allasino e.a., 2004; Andriessen e.a., 2012; 2015; Baert e.a., 2015; Bertrand \& Mullainathan, 2004; Blommaert e.a., 2014; Booth e.a., 2012; Bovenkerk e.a., 1994; Bursell, 2014; Carlsson, 2010; Carlsson \& Rooth; 2007; Cediey \& Foroni, 2008; Dolfing \& Van Tubergen, 2006; Duguet e.a., 2015; Gaddis, 2015; Jacquemet \& Yannelis, 2012; Kaas \& Manger, 2012; McGinnity \& Lunn, 2011; Midtbøen, 2016; Oreopoulos, 2011; voor een meta-analyse, zie Zschirnt \& Ruedin, 2016).

\section{Huidig onderzoek}

Het huidige onderzoek bouwt voort op de hierboven beschreven experimenten waarbij de invloed van delinquentie op arbeidsmarktkansen werd onderzocht. Verschillende factoren die de sterkte van het effect van een veroordeling op de kansen van sollicitanten kunnen beïnvloeden, worden in deze studie systematisch gevarieerd. Zo zal niet één type delict bekeken worden, maar drie verschillende soorten delicten, namelijk geweldsdelicten, vermogensdelicten en zedendelicten, vergeleken met sollicitanten zonder een delinquentieverleden. Deze categorieën

1 De Amerikaanse literatuur maakt vaak onderscheid tussen blanken (Caucasian), Afro-Amerikanen, Latijns-Amerikanen en Aziaten. Dit is anders dan het in Nederland gebruikelijke onderscheid tussen autochtonen en allochtonen, waarin het geboorteland centraal staat. 
zijn gekozen vanwege het feit dat ze verschillen in gepercipieerde ernst en omdat ze van directe invloed kunnen worden geacht voor de uitoefening van bepaalde functies. Een geweldsdelict kan bijvoorbeeld geassocieerd worden met een opvliegende persoonlijkheid waarmee moeilijk valt samen te werken, of een persoon die mogelijk niet correct jegens klanten optreedt. Bij vermogensdelicten zou men bijvoorbeeld de persoon minder snel kunnen vertrouwen met waardevolle zaken. Zedendelinquenten worden vaak gezien als het 'ergste' type delinquenten, in die zin dat wordt gedacht dat zij een stoornis hebben en onverbeterlijk zijn (Jenkins, 1998; Pickett e.a., 2013). Verder zal de verstreken termijn tussen de veroordeling en de sollicitatie worden gevarieerd; we nemen aan dat als er meer tijd is verstreken sinds het delict, dat dit minder zwaar zal worden 'aangerekend'. Ook de sector waarin gesolliciteerd wordt, zal worden meegenomen in het huidige onderzoek. De reden hiervoor is dat er in verschillende sectoren mogelijk anders aangekeken wordt tegen een strafblad, iets waarvoor Baert en Verhofstadt (2013) aanwijzingen vonden. Als laatste zal de etniciteit van de sollicitant worden gevarieerd. Enkele recente studies uit de Verenigde Staten toonden aan dat sollicitanten uit minderheidsgroepen een groter negatief effect ondervinden van een veroordeling bij het vinden van een baan (Pager, 2003; 2007; Pager e.a., 2009b). Onderzoek naar het effect van delinquentie in combinatie met etniciteit op arbeidsmarktkansen buiten de Verenigde Staten is beperkt. Een uitzondering hierop vormt het Nederlandse onderzoek van Dirkzwager en collega's (2015). Zij vonden dat sollicitanten met een niet-westerse (allochtone) achtergrond vaker negatieve reacties ontvingen dan sollicitanten met een westerse (autochtone) achtergrond. Om te onderzoeken of een veroordeling de kansen van westerse en niet-westerse sollicitanten in Nederland op eenzelfde manier beïnvloedt, zullen wij in dit onderzoek ook etniciteit betrekken. Samenvattend beantwoorden we in dit onderzoek de volgende onderzoeksvraag:

In hoeverre hangt de invloed van een veroordeling op arbeidsmarktkansen af van (a) het type delict waarvoor men is veroordeeld, (b) de verstreken termijn sinds het plegen van het delict, (c) de arbeidsmarktsector, en (d) de etniciteit van de sollicitant?

\section{Methoden}

\section{Dataverzameling}

Om het effect van het hebben van een strafblad op arbeidsmarktkansen te onderzoeken is een veldexperiment uitgevoerd waarbij fictieve personen solliciteren op internetvacatures. Binnen de sollicitaties is at random gevarieerd op type delict, verstreken termijn tussen veroordeling en sollicitatie en etniciteit. De manipulatie delinquentie bestond uit vier condities, de fictieve sollicitant kon een zeden-, gewelds- of vermogensdelict hebben gepleegd of geen delict. Verder is gevarieerd in de verstreken termijn tussen een veroordeling en een sollicitatie. Zo kon de veroordeling kort geleden zijn (vorig jaar) of langere tijd geleden (drie jaar, en daarmee tijdens de late adolescentie van de fictieve sollicitant). Ook kon de solli- 
citant een Nederlandse (westerse) achtergrond hebben of een niet-westerse achtergrond. Dit leidt tot een $4 \times 2 \times 2$ between subjects design.

In het huidige onderzoek zijn 535 sollicitaties verzonden in twee periodes. ${ }^{2}$ In de eerste periode, van 7 mei 2013 tot 5 juni 2013, zijn 295 sollicitaties verzonden. In de tweede periode, van 29 september 2013 tot 11 december 2013, zijn 240 sollicitaties verzonden. Er is uitsluitend gereageerd op internetvacatures via bekende vacaturewebsites. De vacatures betroffen banen in Nederland, in drie verschillende sectoren: bouw, logistiek en techniek. Tussen de drie sectoren is ook at random gevarieerd. Binnen de sectoren is gesolliciteerd op functies die een laag opleidingsniveau vereisen, zoals timmerman, elektromonteur, orderpicker en chauffeur. Van de 535 sollicitaties zijn er 15 verwijderd door fouten in het verstuurde $\mathrm{cv}$ of in de motivatiebrief. Het totale aantal in de analyse meegenomen sollicitaties komt hiermee op 520 . Het gaat hierbij om een sollicitatie van één fictieve persoon (met of zonder een bepaald type delict) op één vacature. Hiervoor is gekozen om geen argwaan te wekken bij de potentiële werkgevers. De kans hierop zou aanzienlijk zijn geweest wanneer een potentiële werkgever verschillende brieven had gekregen waarin het hebben gepleegd van een delict wordt gemeld. Dit is namelijk niet gebruikelijk volgens de door ons geraadpleegde experts bij uitzendbureaus.

Veel aandacht is uitgegaan naar de totstandkoming van een passende sollicitant voor de verschillende functies. De sollicitant dient namelijk voor werkgevers zo aantrekkelijk te zijn dat hij in beginsel voor de functie in aanmerking komt. Hierdoor is het waarschijnlijk dat wanneer een sollicitant een positieve of negatieve reactie ontvangt, dit toe te schrijven is aan de manipulatie en niet aan het cv of de motivatiebrief. Om het cv en de motivatiebrief zo realistisch mogelijk te maken is gekeken naar eerdere onderzoeken (o.a. Dirkzwager e.a., 2015) en is vooraf gesproken met medewerkers van verschillende uitzendbureaus. Op basis van deze informatie zijn drie algemene cv's en motivatiebrieven opgesteld, toegesneden op de drie branches, die telkens aangepast konden worden, zodat de sollicitant aan de gestelde functie-eisen voldeed. De experts bij de benaderde uitzendbureaus hebben kritisch naar de opgestelde cv's en de motivatiebrieven gekeken, resulterend in realistische en vergelijkbare cv's en motivatiebrieven.

De cv's en motivatiebrieven hebben betrekking op een fictieve mannelijke sollicitant van 20 jaar. De gekozen leeftijd is relevant voor de conditie verstreken termijn tussen de veroordeling en de sollicitatie. Hierbij wordt in de brief onderscheid gemaakt tussen de vermelding drie jaar geleden (lange termijn) en een jaar geleden (korte termijn). Bij de langere termijn betekent dit dat de fictieve sollicitant ten tijde van de veroordeling nog net niet volwassen was. Door te variëren hoelang geleden het delict is gepleegd, kan na worden gegaan of werkgevers minder zwaar aan een strafblad tillen als het delict langer geleden gepleegd is, en wel ten tijde van de late adolescentie. Alle fictieve sollicitanten hadden dezelfde werkervaring en de behaalde opleiding was telkens van gelijkwaardig niveau. Ook zijn

2 Dit is om praktische redenen: aan het einde van de eerste periode waren er weinig nieuwe sollicitaties meer beschikbaar. Eind september bleken er weer voldoende nieuwe vacatures te zijn, waarop besloten is verder te gaan met de dataverzameling. 
de sollicitanten allen in Nederland geboren en hebben zij een Nederlandse opleiding genoten. De cv's en motivatiebrieven verschillen dus alleen met betrekking tot de manipulaties en de sectoren waarin gesolliciteerd wordt.

De informatie over de eventuele veroordeling is verwerkt in de motivatiebrief. De fictieve sollicitant geeft in de motivatiebrief allereerst aan geïnteresseerd te zijn in de baan. Vervolgens geeft de sollicitant aan dat hij veroordeeld is voor een delict (manipulatie type delinquentie en tegelijkertijd verstreken termijn). De verwoording van de delicten in de motivatiebrief is zo, dat het geweldsdelict omschreven wordt als een vechtpartij en het vermogensdelict als een diefstal. Voor zedendelict is de omschrijving 'zedendelict' gebleven na overleg met de arbeidsmarktexperts, die een specifiekere omschrijving onrealistisch vonden. Als reden voor het vermelden van de veroordeling is de volgende zin opgenomen in de motivatiebrief: 'Bij mijn vorige sollicitatie ben ik in de problemen gekomen want toen ben ik pas later eerlijk geweest over mijn veroordeling. Daarom wil ik er nu graag meteen eerlijk over zijn.' In overleg met de experts van het uitzendbureau werd dit als een geloofwaardige redenering gezien voor het vermelden van een veroordeling. Normaliter is een sollicitant hier niet toe verplicht en vaak wordt ook aangeraden veroordelingen niet te vermelden indien deze niet van belang zijn voor de uitoefening van de functie. De sollicitant die een delict had gepleegd, vermeldde telkens dat hij voor het delict een taakstraf had gekregen, daarmee een signaal afgevend dat het een relatief licht delict betrof. Wij konden niet per vacature voorspellen of het betreffende delict überhaupt een beletsel zou zijn om een verklaring omtrent gedrag (VOG) af te geven; door de vermelding dat er een taakstraf was opgelegd, was dat allereerst minder waarschijnlijk, en waren de delicten ten tweede in ernst enigszins 'gelijkgetrokken', waardoor eventuele verschillen in de kans op een positieve reactie meer aan de aard van het delict dan aan de ernst daarvan toe te schrijven zouden zijn.

Om het effect van etnische achtergrond te onderzoeken zijn twee condities gehanteerd. Er is gebruik gemaakt van een duidelijk 'Hollandse' naam en een nietwesterse naam. Om een eerste indruk te krijgen van de sollicitanten gebruiken werkgevers tegenwoordig vaak sociale media. Er is om deze reden gekozen voor twee op de sociale media veel voorkomende namen die, ook al was de sollicitant telkens fictief, niet te herleiden zijn naar één persoon.

Alle fictieve sollicitanten kregen een persoonlijk e-mailadres en een telefoonnummer. De telefoon werd echter nooit opgenomen, waardoor deze doorschakelde naar een door de provider gefaciliteerde voicemail. Hierdoor kon de werkgever na het horen van een computerstem die het telefoonnummer opnoemt, een bericht achterlaten. De ontvangen voicemail- en e-mailberichten zijn gebruikt om de reacties van werkgevers te registreren. Bij een positieve reactie werd door de onderzoekers zo snel mogelijk een standaard reactie gestuurd waarin de sollicitant aangaf niet langer geïnteresseerd te zijn in verband met een reeds gevonden andere baan.

Tegen een experiment als het onderhavige kunnen ethische bezwaren ingebracht worden. Zo waren de werkgevers in de huidige studie er niet van op de hoogte dat de brief fictief was en onderdeel uitmaakte van een wetenschappelijk onderzoek. In de wetenschap is dit niet gebruikelijk, aan deelnemers aan wetenschappelijk 
onderzoek wordt immers over het algemeen toestemming tot deelname gevraagd voor de aanvang van een onderzoek. Uitzonderingen op deze standaard werkwijze zijn wel mogelijk. Dit geldt onder andere voor onderzoeken waarbij het noodzakelijk is natuurlijk gedrag te bestuderen en waar een dergelijke toestemmingsvraag het onmogelijk zou maken dit te doen (KNAW, 2003). Om deze reden zijn het onderzoek en de werkwijze voorgelegd aan de ethische commissie van de Vrije Universiteit Amsterdam (Commissie Ethiek Rechtswetenschappelijk \& Criminologisch Onderzoek - CERCO). Benadrukt is dat de resultaten vertrouwelijk behandeld en gepresenteerd worden. De aangeschreven werkgevers in het onderzoek worden belast met de beoordeling van een sollicitatie. Om deze belasting te beperken is zo snel mogelijk gereageerd op reacties van werkgevers. Hierdoor is voor hen snel duidelijk dat geen verdere aandacht besteed hoeft te worden aan de betreffende sollicitatie. De ethische commissie heeft het onderzoeksdesign en de werkwijze positief beoordeeld.

\section{Variabelen}

De afhankelijke variabele in het onderzoek betreft de reactie van de werkgever op de sollicitatie. De reacties op de sollicitaties zijn in twee categorieën ingedeeld: positieve reacties en afwijzingen. Een uitnodiging voor een (kennismakings)gesprek, de vraag om nadere informatie over de sollicitant en de vraag om contact op te nemen met de werkgever zijn gekwalificeerd als positieve reacties; een negatieve of geen reactie is geclassificeerd als afwijzing.

De onafhankelijke variabelen in het onderzoek betreffen de manipulaties: (type) delinquentie, verstreken termijn tussen veroordeling en sollicitatie en als laatste etniciteit. Delinquentie is kenbaar gemaakt in de motivatiebrief, expliciet is daar het type delict genoemd. Dit wordt feitelijk, maar enigszins afstandelijk beschreven. Er wordt gemeld dat de persoon een taakstraf heeft ondergaan (waaruit men kan afleiden dat het niet een relatief zwaar delict betrof). Bij de verstreken termijn tussen veroordeling en sollicitatie werd onderscheid gemaakt tussen kort en lang geleden, hetgeen vermeld werd in de motivatiebrief. Etniciteit ligt besloten in de naam van de sollicitant. Gekozen is voor een oosters klinkende achternaam en een islamitische voornaam, omdat men dit duidelijk zal herkennen als nietwesters (Blommaert e.a., 2013). Naast de experimentele condities zal in de analyse ook onderscheid worden gemaakt in de arbeidsmarktsectoren waarin de bedrijven opereren. Binnen de bouwsector zijn 164 sollicitaties verstuurd (31,5 procent), bedrijven in de technieksector ontvingen 177 sollicitaties (34 procent) en naar vacatures binnen de logistieksector zijn 179 sollicitaties (34,4 procent) verstuurd.

\section{Analyses}

Om te onderzoeken hoe de veroordeling van invloed is op de arbeidsmarktkansen van sollicitanten zijn de percentages positieve reacties bekeken. Deze positieve reacties worden weergegeven in een grafiek waarin ook de 90 procentbetrouwbaarheidsintervallen zijn aangegeven. Wanneer de betrouwbaarheidsintervallen niet overlappen, spreken we van een statistisch significant verschil tussen de condities. Omdat de verschillende condities in alle brieven onafhankelijk van elkaar 
werden gevarieerd, is het mogelijk om zowel de losse effecten van de condities als de combinaties te analyseren. Dit is dan ook gebeurd in de verschillende grafieken waarop de resultatensectie is gebaseerd. Allereerst is de grafiek voor de verschillende typen delict weergegeven (figuur 1). Dit is de basis van het experiment, het hoofdeffect. In de daaropvolgende grafieken zullen de experimentele condities verder uitgesplitst worden door het aantal positieve reacties per type delict weer te geven in interactie met de termijn die verstreken is sinds het delict (figuur 2), de sector (figuur 3) en etniciteit (figuur 4). Hierdoor is het mogelijk te bekijken hoe deze drie variabelen samenhangen met het type delict en het aantal ontvangen positieve reacties.

Het is van belang op te merken dat door de uitsplitsingen de celvullingen uiteraard dalen. Bovendien was het aantal positieve reacties (zeker in sommige condities) lager dan we aanvankelijk verwacht hadden. De nauwkeurigheid waarmee we de conditionele effecten kunnen schatten, is daardoor lager. Om deze redenen is ervoor gekozen de betrouwbaarheidsintervallen te berekenen met een alfa van 0,1 . Dat betekent dat we met 90 procent zekerheid kunnen stellen dat bij herhaling van het experiment een percentage gevonden wordt in dezelfde range. Uiteraard zijn er beperkingen verbonden aan de keuze voor een alfa van 0,1. Deze zullen worden besproken in de discussie.

\section{Resultaten}

\section{Type delict}

Figuur 1 laat zien dat sollicitanten die geen delict meldden in hun motivatiebrief vaker - in bijna 20 procent van de gevallen - een positieve reactie ontvingen. $\mathrm{Zij}$ worden gevolgd door sollicitanten met een veroordeling wegens een geweldsdelict, die in 18,4 procent van de gevallen een positieve reactie op hun sollicitatie kregen. Van diegenen die een veroordeling wegens een vermogensdelict hadden opgebiecht in de motivatiebrief ontving bijna 13 procent een positieve reactie. Zedendelinquenten ontvingen, zoals verwacht, het minst vaak - in 10,3 procent van de gevallen - een positieve reactie. De betrouwbaarheidsintervallen die zijn weergegeven in figuur 1 , laten echter voor alle categorieën een overlap zien. Dit betekent dat de kans op een positieve reactie op een sollicitatie niet statistisch significant verschilt tussen sollicitanten die geen veroordeling meldden en degenen die melding maakten van veroordelingen wegens verschillende soorten delicten. Wanneer sec gekeken wordt naar sollicitanten die geen delict pleegden en sollicitanten die wel een delict pleegden (hier niet weergegeven), wordt ook geen statistisch significant verschil gevonden.

\section{Type delict en termijn}

Figuur 2 geeft de percentages positieve reacties weer voor werkzoekenden veroordeeld voor de verschillende typen delicten, uitgesplitst naar de termijn tussen de veroordeling en de sollicitatie. Kort geleden houdt in dat de veroordeling een jaar geleden was en bij lang geleden was dit drie jaar. We verwachtten dat wanneer een 


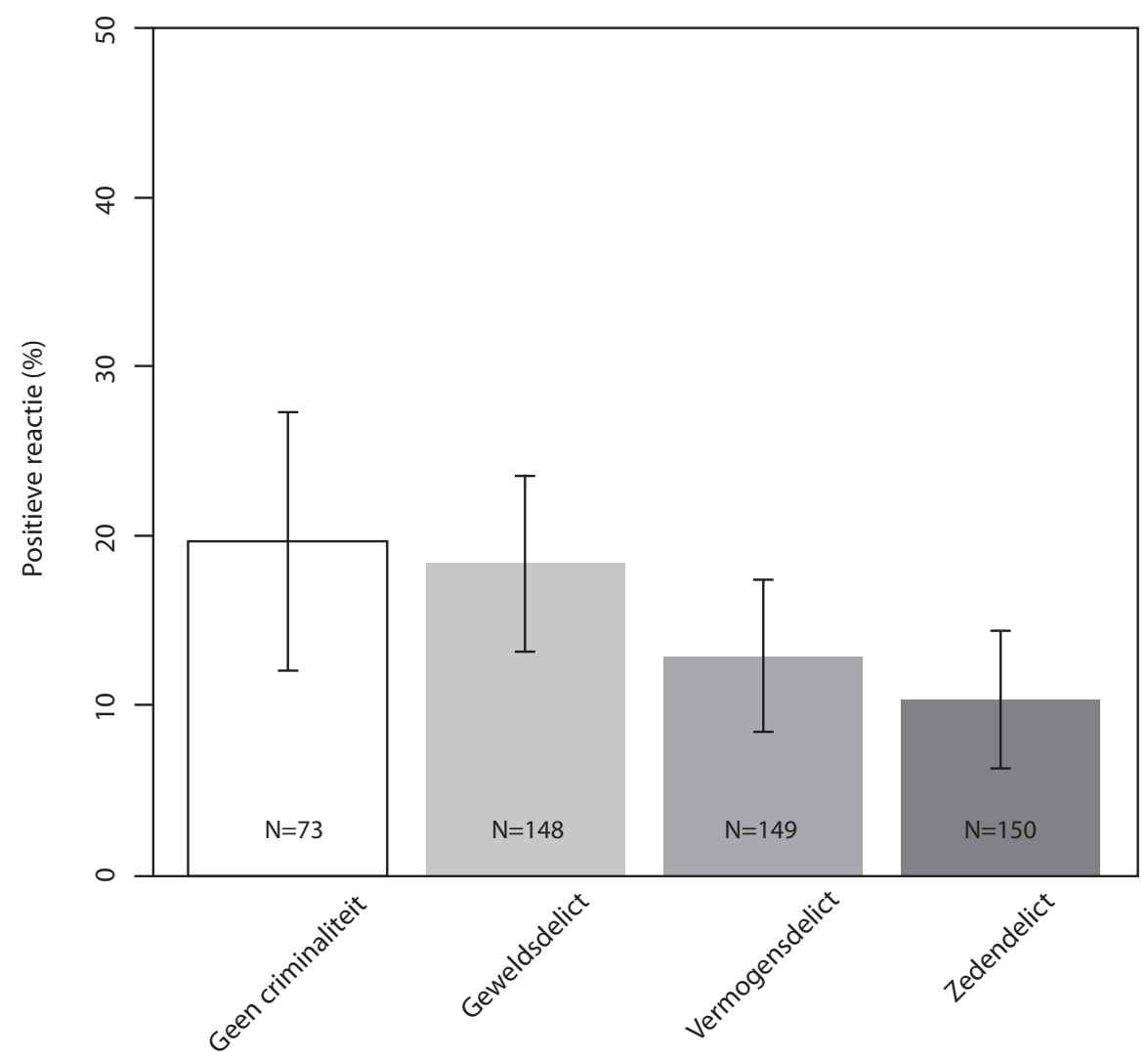

Figuur 1 Percentage positieve reacties per type delict

delict langer geleden was gepleegd, deze personen een grotere kans zouden hebben op een positieve reactie. Gemiddeld genomen worden echter geen statistisch significante verschillen gevonden naar de termijn tussen veroordeling en sollicitatie. Figuur 2 laat echter voor sollicitanten die zijn veroordeeld wegens vermogensdelicten een onverwacht en moeilijk te verklaren, maar statistisch significant verschil zien: wanneer sollicitanten lang geleden veroordeeld zijn, blijkt dit voor een significant lager percentage (5,6 procent) positieve reacties te zorgen dan wanneer de veroordeling voor het vermogensdelict kortere tijd geleden is (21,3 procent, bijna vier keer zoveel positieve reacties). Deze bevinding is tegengesteld aan de hierboven genoemde verwachting. Een mogelijke verklaring hiervoor ontbreekt. Uiteraard valt niet geheel uit te sluiten dat dit resultaat een toevalligheid in de data is door de relatief lage celvulling en het überhaupt geringe aantal positieve reacties (zie discussie).

Figuur 2 laat daarnaast nog een ander statistisch significant verschil zien, dat naar voren komt als we ook kijken naar andere vergelijkingen dan enkel die tussen sollicitanten die hetzelfde type delict pleegden. Zo is de kans op een positieve 


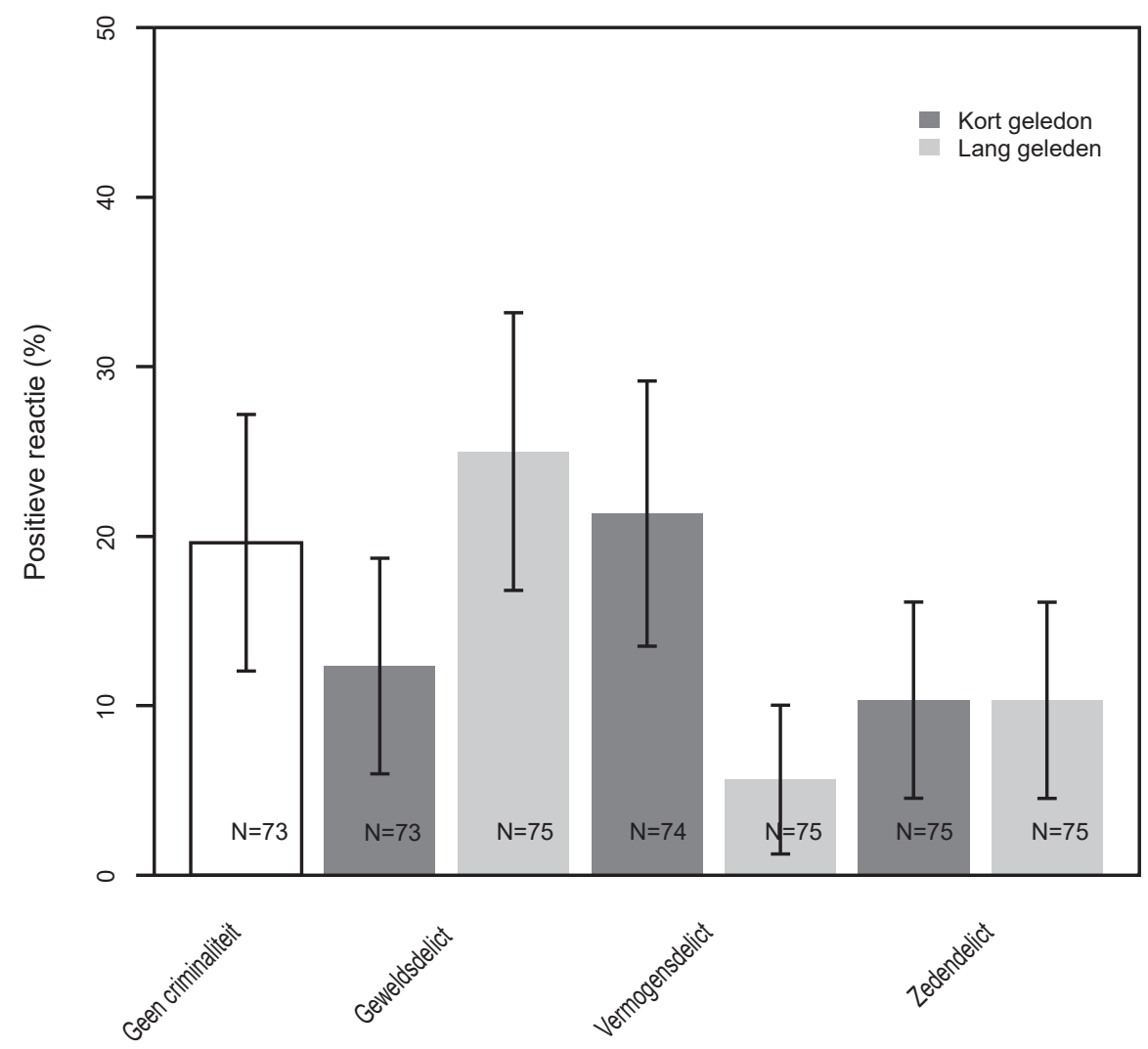

Figuur 2 Percentage positieve reacties per type delict uitgesplitst naar termijn

reactie groter voor sollicitanten die langer geleden zijn veroordeeld wegens een geweldsdelict dan voor sollicitanten die langer geleden zijn veroordeeld wegens een vermogensdelict.

\section{Type delict en sector}

Figuur 3 toont de kans op een positieve reactie naar de sector waarin gesolliciteerd is, wederom per type delict. Hieruit valt op te maken dat de kans op een positieve reactie in de bouw altijd het hoogst is, ongeacht of de sollicitant in het verleden is veroordeeld en waarvoor hij is veroordeeld. Door sollicitanten met een veroordeling voor een geweldsdelict worden aanzienlijk minder positieve reacties ontvangen bij een sollicitatie in de logistieksector dan wanneer gesolliciteerd wordt op een functie in de bouw. Bij een sollicitatie in de bouw door een persoon met een veroordeling voor een geweldsdelict is het aantal positieve reacties bijna 7,5 keer groter dan het aantal positieve reacties in de logistieksector (31 procent in de bouw ten opzichte van 4,2 procent in de logistiek). In de technieksector is 
het aantal positieve reacties bijna zes keer groter dan in de logistieksector (24,2 procent ten opzichte van 4,2 procent). Deze verschillen in de percentages positieve reacties zijn alle statistisch significant. Wat betreft vermogensdelicten worden vergelijkbare resultaten gevonden. In de logistieksector worden aanzienlijk minder positieve reacties ontvangen in vergelijking met de twee andere sectoren. In de bouw is wederom de kans op een positieve reactie het grootst, daar wordt een percentage van 5,7 keer meer positieve reacties gevonden ten opzichte van het aantal positieve reacties in de logistiek. Dit verschil is statistisch significant. Voor de technieksector is het percentage positieve reacties vier keer groter dan in de logistieksector. Dit verschil is echter niet statistisch significant. Voor zedendelicten wordt wederom gevonden dat men in de bouw het grootste aantal positieve reacties ontvangt (22 procent). Binnen de logistiek- en de technieksector zijn de percentages positieve reacties bijna gelijk (6,4 procent en 4,2 procent). Alleen de percentages van de bouw- en technieksector verschillen statistisch significant voor zedendelinquenten.

Figuur 3 laat verder nog zien dat binnen elke sector de verschillen tussen sollicitanten veroordeeld voor verschillende typen delicten telkens niet statistisch significant zijn. Dat is in lijn met onze eerdere conclusie dat er geen statistisch significante verschillen zijn naar het type delict. Overigens zien we dat het hebben van een veroordeling het grootste effect heeft in de logistieksector; de verschillen tussen personen die wel en niet een veroordeling hebben, zijn echter telkens niet statistisch significant.

\section{Type delict en etniciteit}

Uit figuur 4 kan worden opgemaakt in hoeverre de effecten voor type delict afhangen van etniciteit. Duidelijk zichtbaar in de figuur is het hogere percentage positieve reacties voor westerse sollicitanten (in de figuur aangeduid als autochtoon; niet-westerse sollicitanten worden aangeduid als allochtoon) bij alle typen delict. Niet-veroordeelde westerse sollicitanten kregen in 32,1 procent positieve reacties, terwijl dit slechts 9,1 procent was bij niet-veroordeelde niet-westerse sollicitanten. Met bijna 3,5 keer meer positieve reacties is dit verschil statistisch significant. Voor de andere typen delict gelden dezelfde verhoudingen. Bij geweldsdelicten kregen westerse sollicitanten bijna drie keer zoveel positieve reacties (28,1 procent voor westerse sollicitanten en 10,3 procent voor niet-westerse sollicitanten). Het verschil werd nog groter voor vermogensdelicten: westerse sollicitanten ontvangen daar in 21 procent van de gevallen een positieve reactie tegenover 5,7 procent voor niet-westerse sollicitanten. Dit is bijna vier keer meer kans op een positieve reactie voor westerse sollicitanten met een veroordeling voor een vermogensdelict dan voor niet-westerse sollicitanten die een vermogensdelict hebben gepleegd. Voor zedendelicten geldt een vergelijkbare factor, de westerse sollicitanten ontvangen vier keer zoveel positieve reacties dan niet-westerse sollicitanten veroordeeld voor een zedendelict. Alle bovenstaande verschillen zijn statistisch significant, waaruit blijkt dat niet-westerse sollicitanten, ongeacht of en voor welk type delict zij een veroordeling meldden, altijd significant minder positieve reacties ontvingen. 


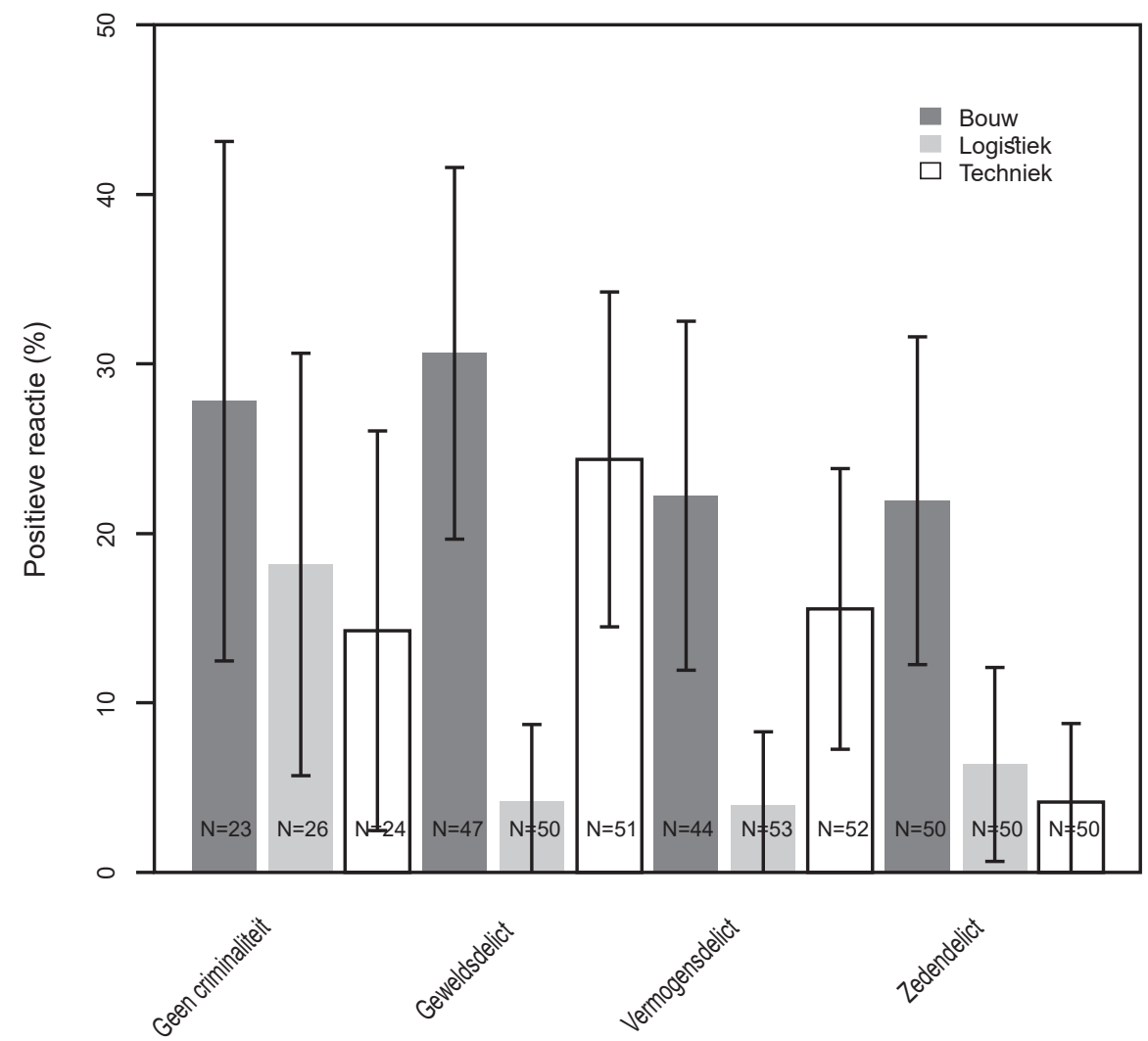

Figuur 3 Percentage positieve reacties per type delict uitgesplitst naar sector

De verschillen zijn zelfs zo groot dat we zien dat een westerse sollicitant met een veroordeling voor een geweldsdelict meer kans heeft op een positieve reactie dan een niet-westerse sollicitant met een leeg strafblad.

\section{Conclusie en discussie}

Het hebben van een baan geldt als een van de belangrijkste beschermende factoren tegen criminaliteit. Toch blijkt uit verschillende onderzoeken dat mensen met een strafblad vaak moeilijkheden ondervinden in de zoektocht naar een baan. In dit onderzoek is door middel van een veldexperiment onderzocht of personen met een strafblad minder vaak een positieve reactie krijgen op een sollicitatie. Daarbij gingen we na of het effect van een veroordeling op de kans dat een werkzoekende een positieve reactie ontving op een sollicitatie anders was al naar gelang het type delict, de tijdsduur verstreken sinds de veroordeling, de sector waarin gesolliciteerd werd en de etniciteit van de sollicitant. 


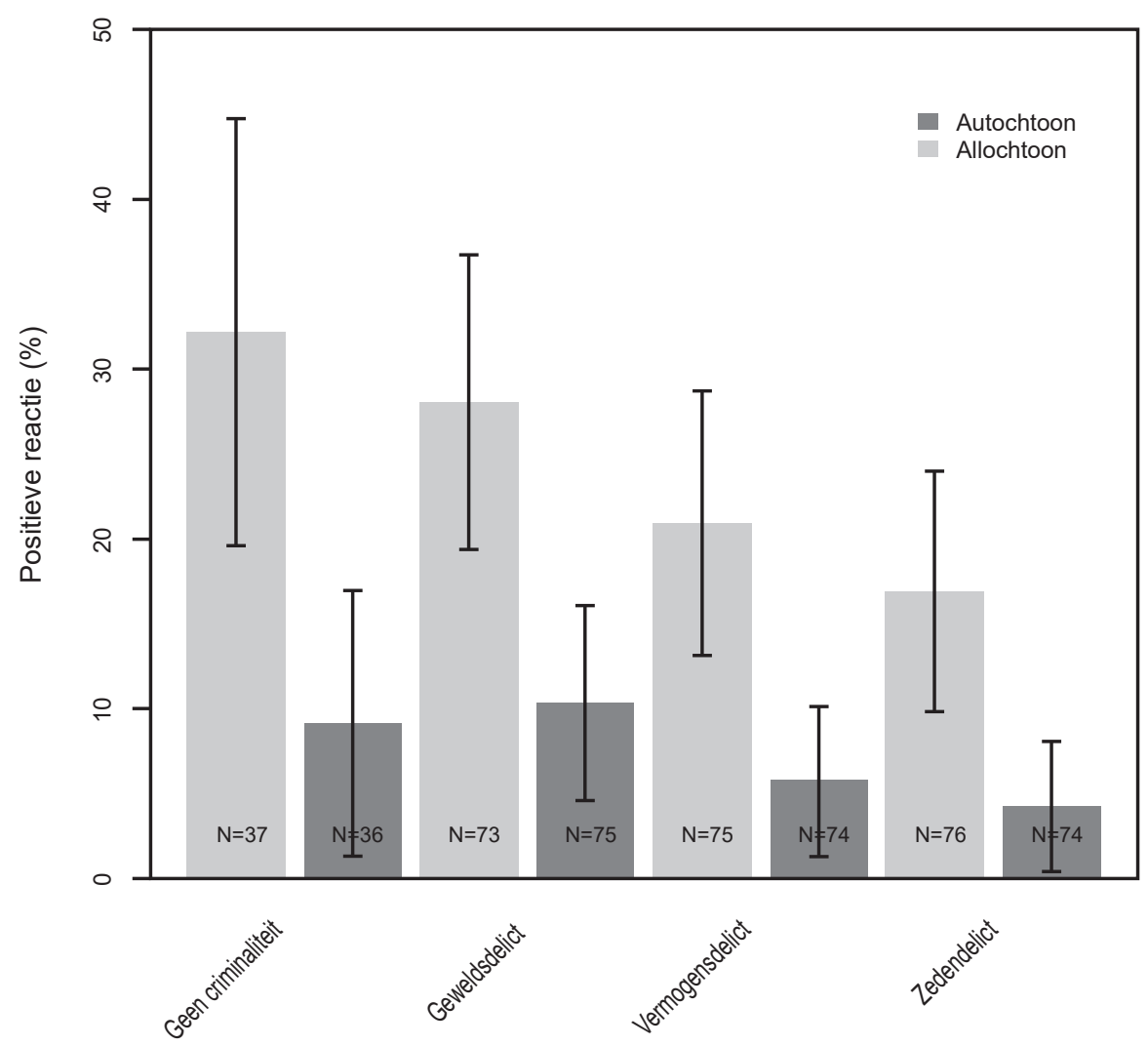

\section{Figuur $4 \quad$ Percentage positieve reacties per type delict uitgesplitst naar etniciteit}

Opvallend genoeg vinden wij dat sollicitanten met een strafblad niet een statistisch significant lagere arbeidsmarktkans hebben in vergelijking met sollicitanten zonder strafblad. Deze uitkomst wijkt af van resultaten uit eerdere, voornamelijk buitenlandse, onderzoeken. Eerder Nederlands onderzoek van Dirkzwager en collega's (2015) toonde echter ook al aan dat ex-gedetineerden niet significant vaker een negatieve reactie ontvingen ten opzichte van personen die niet eerder gedetineerd waren geweest. Dit versterkt het vermoeden dat tussen landen verschillen bestaan ten aanzien van het aannemen van sollicitanten met een strafblad. In de Verenigde Staten, het land waar de meeste experimenten zijn gedaan, geldt over het algemeen een zeer punitief klimaat. Daarnaast zijn werkgevers daar aansprakelijk voor delicten die door werknemers gepleegd worden tijdens werktijd (Bushway, 2004). Dit maakt dat sollicitanten met een strafblad mogelijk meer risico met zich meebrengen voor de werkgever en om die reden mogelijk vaker afgewezen worden dan personen zonder strafblad. Met andere woorden, deze personen worden in de Verenigde Staten vaker geassocieerd met een negatief signaal of label. In Nederland is dit niet het geval en zijn werkgevers mogelijk minder 
geneigd iemand met een strafblad af te wijzen, vooral als het eerdere delict de uitoefening van het beroep niet in de weg staat. In de Nederlandse wetgeving is dan ook bepaald dat men voor bepaalde beroepen een verklaring omtrent gedrag (VOG) nodig heeft voor de uitoefening van dat beroep (Beleidsregels VOG-NP-RP 2013). De criteria waarop getoetst wordt voor afgifte van een VOG zijn direct van toepassing op het beroep. Zo zal iemand die veroordeeld is voor het stelen van geld mogelijk geen VOG krijgen voor een baan met financiële verantwoordelijkheden. De werkgever is verplicht deze VOG aan te vragen en wanneer deze niet afgegeven wordt, zal de potentiële werknemer niet aangenomen kunnen worden voor de betreffende baan. De meeste werkgevers zijn op de hoogte van deze gang van zaken en handelen daar dan ook naar bij de beoordeling van sollicitaties.

Een andere mogelijke verklaring voor het vinden van een gelijkwaardige arbeidsmarktkans voor sollicitanten met een veroordeling is dat de omschreven delicten als relatief licht kunnen worden geïnterpreteerd. In het huidige experiment gebeurt dit door de vermelding dat als bestraffing een taakstraf is uitgevoerd en in het experiment van Dirkzwager en collega's (2015) blijkt dit uit een korte detentieperiode. Zoals al eerder aangehaald, lijken de resultaten van eerdere veldexperimenten een aanwijzing te geven dat een lichtere straf samen zou kunnen hangen met een kleiner effect van veroordeling op arbeidsmarktkansen van sollicitanten. Studies waarin sollicitanten zwaardere straffen vermeldden, vonden dan ook doorgaans een groter effect (Baert \& Verhofstadt, 2013; Decker e.a., 2014; Deliens, 1983; Dirkzwager e.a., 2015; Galgano, 2009; Pager, 2003; 2007; Pager e.a., 2009a; 2009b). In toekomstige onderzoeken zou meer aandacht aan deze factor besteed kunnen worden door te variëren in het type straf en de strafduur.

De beleidsregels omtrent de VOG hebben mogelijk ook invloed op de gevonden resultaten voor de verschillende sectoren waarin gesolliciteerd is. Zo is het niet ondenkbaar dat sollicitanten die een bepaald type delict hebben gepleegd vaker afgewezen zullen worden in bepaalde sectoren. Uit de resultaten van deze studie is gebleken dat sollicitanten in de bouw de grootste kans hebben op een positieve reactie. Dit is te verwachten, aangezien binnen de bouw minder vaak een VOG noodzakelijk zal zijn voor de uitvoering van het werk. Daartegenover staat dat in de logistieke sector sollicitanten met een gewelds- of een vermogensdelict op hun strafblad een statistisch significant lagere kans hebben op een positieve reactie. Een mogelijke verklaring hiervoor is dat men in de logistieksector de werknemers moet vertrouwen met goederen die vervoerd moeten worden. Wanneer iemand een vermogensdelict heeft gepleegd, kan dit tot een hogere risico-inschatting leiden bij de werkgever, waarop deze kan besluiten liever geen personen aan te nemen met een vermogensdelict op hun strafblad.

Verreweg het sterkste effect dat we vonden in het huidige experiment is dat nietwesterse sollicitanten een statistisch significant lager aantal positieve reacties ontvingen dan westerse sollicitanten. Dit geldt voor alle sollicitanten, ongeacht of ze zijn veroordeeld, en ongeacht het type delict. Deze bevinding sluit aan bij de uitkomsten van het Nederlandse experiment van Dirkzwager en collega's (2015) en bij experimenten in de Verenigde Staten die naast de invloed van het hebben van een strafblad ook de invloed van de etniciteit van sollicitanten onderzochten (Decker e.a., 2014; Galgano, 2009; Pager, 2003; 2007; Pager e.a., 2009a; 2009b). 
Bovendien is deze bevinding in lijn met de uitkomsten van experimenten waarbij de focus lag op de invloed van de etniciteit van sollicitanten - en het wel of niet hebben van een strafblad dus buiten beschouwing werd gelaten - in Nederland (Bovenkerk e.a., 1994; Dolfing \& Van Tubergen, 2006; Andriessen e.a., 2012; 2015; Blommaert e.a., 2014) en internationaal (Allasino e.a., 2004; Baert e.a., 2015; Bertrand \& Mullainathan, 2004; Booth e.a., 2012; Bursell, 2014; Carlsson, 2010; Carlsson \& Rooth, 2007; Cediey \& Foroni, 2008; Duguet e.a., 2015; Gaddis, 2015; Jacquemet \& Yannelis, 2012; Kaas \& Manger, 2012; McGinnity \& Lunn, 2011; Midtbøen, 2016; Oreopoulos, 2011; voor een meta-analyse, zie Zschirnt \& Ruedin, 2016). Aangezien alle sollicitanten gelijkwaardige competenties hadden, is dit een des te opvallende bevinding. Wrang is de bevinding dat zelfs sollicitanten met een niet-westerse naam zonder strafblad nog een lagere kans hadden op een positieve reactie dan sollicitanten met een westerse naam die voor een geweldsdelict veroordeeld waren. Deze bevinding is in overeenstemming met eerdere Amerikaanse experimenten (Pager, 2003; 2007; Pager e.a., 2009a; 2009b). Al met al roepen deze bevindingen op tot contemplatie. Het feit dat ook in ons onderzoek minderheden met een onberispelijk strafrechtelijk verleden het soms aflegden tegen 'Hollandse' sollicitanten met een delict op de kerfstok, stemt niet tot vrolijkheid.

Onze studie heeft een aantal beperkingen. De belangrijkste hiervan is de relatief kleine celvulling in de verschillende condities van dit experiment, zeker gegeven het geringe aantal positieve reacties in sommige condities. Om deze reden is gekozen om te rekenen met 90 procentbetrouwbaarheidsintervallen, met een alfa van 0,1 dus. De resultaten in dit artikel zijn dus gebaseerd op een groter verwerpingsgebied, wat betekent dat enige voorzichtigheid geboden is bij de interpretatie van de uitkomsten. Voor toekomstige experimenten waarin de arbeidsmarktkansen van veroordeelden worden bestudeerd en waarin wordt onderzocht of het effect van een strafblad verschilt onder bepaalde condities raden we dan ook aan gebruik te maken van een (nog) grotere sample. Op deze manier zou een kleiner verwerpingsgebied aangehouden kunnen worden vanwege de grotere sample. Uiteraard hebben de beperking van de huidige relatief kleine steekproef en de 90 procentbetrouwbaarheidsintervallen consequenties voor de beantwoording van de onderzoeksvraag. Het is dan ook op dit moment niet mogelijk een sluitend antwoord te geven op de vraag of de sterkte van het effect van het hebben van een strafblad afhangt van het type delict, de tijd die is verstreken sinds de veroordeling, de arbeidsmarktsector of de etniciteit van de sollicitant. De kleine aantallen sollicitanten per conditie maakten het vaak niet mogelijk om statistisch significante effecten vast te stellen, ook al waren de effecten in absolute zin vaak fors. Een ander nadeel van ons onderzoek betreft de experimentele manipulatie van het type delict. In de motivatiebrief geeft de fictieve respondent aan dat hij bij een eerdere sollicitatie problemen heeft gehad omdat hij niet direct het delict kenbaar had gemaakt aan de potentiële werkgever. Hierdoor wordt de potentiële werkgever in het experiment als het ware 'geprimed' op het feit dat een veroordeling effect kan hebben op zijn of haar keuze. Dit is ogenschijnlijk een nadeel van de experimentele opzet, maar onze resultaten laten zien dat zelfs ondanks deze priming er geen effect gevonden wordt van type delict. Voor etniciteit vonden we 
wel een duidelijk effect, terwijl bij die manipulatie geen sprake was van enige expliciete priming. Een voorzichtige conclusie zou dus kunnen zijn dat delinquentie er inderdaad niet of nauwelijks toe doet bij een sollicitatie.

Helaas was het in deze studie niet mogelijk de afwegingen van één potentiële werkgever te vergelijken ten aanzien van sollicitanten met verschillende delictgeschiedenissen. Door in ons design te variëren naar drie verschillende typen delict is het niet mogelijk dezelfde werkgever meerdere varianten voor te leggen. Dit zou naar onze inschatting te veel argwaan wekken.

Hoewel in dit onderzoek al verschillende conditionele effecten zijn belicht, verdienen ook andere conditionele effecten, zoals de hierboven genoemde type straf of duur van de straf, aandacht in vervolgonderzoek. Ook zou het interessant zijn om te bekijken of het effect van het hebben van een strafblad hetzelfde is voor verschillende leeftijdscategorieën en voor mannen en vrouwen. Dergelijk onderzoek is niet alleen voor theorievorming van belang, maar ook voor instanties die veroordeelden begeleiden bij hun terugkeer in de maatschappij.

\section{Literatuur}

Allasino, E., Reyneri, E., Venturini, A. \& Zincome, G. (2004). Labour market discrimination against migrant workers in Italy. ILO International Migration Papers, 67. Geneve: International Labour Organisation (ILO).

Andriessen, I., Ent, B. van der, Linden, M. van der \& Dekker, G. (2015). Op afkomst afgewezen. Onderzoek naar discriminatie op de Haagse arbeidsmarkt. Den Haag: Sociaal en Cultureel Planbureau.

Andriessen, I., Nievers, E., Dagevos, J. \& Faulk, L. (2012). Ethnic discrimination in the Dutch labor market. Work and Occupations, 39(3), 237-269.

Baert, S. \& Verhofstadt, E. (2013). Labour market discrimination against former juvenile delinquents: evidence from a field experiment. Discussion Paper no. 7845. Bonn: Institute for Study of Labor.

Baert, S., Cockx, B., Gheyle, N. \& Vandamme, C. (2015). Is there less discrimination in occupations where recruitment is difficult? ILR Review, 68(3), 467-500.

Becker, G.S. (1964). Human capital. New York: Columbia University Press.

Becker, G.S. (1968). Crime and punishment: an economic analysis. Journal of Political Economy, 78, 169-217.

Bertrand, M. \& Mullainathan, S. (2004). Are Emily and Greg more employable than Lakisha and Jamal? A field experiment on labor market discrimination. American Economic Review, 94(4), 991-1013.

Blommaert, L., Coenders, M. \& Tubergen, F. van (2014). Discrimination of Arabic-named applicants in the Netherlands. An internet-based field experiment examining different phases in online recruitment procedures. Social Forces, 92(3), 957-982.

Booth, A.L, Leigh, A. \& Varganova, E. (2012). Does ethnic discrimination vary across minority groups? Evidence from a field experiment. Oxford Bulletin of Economics and Statistics, 74(4), 547-573.

Boshier, R. \& Johnson, D. (1974). Does conviction affect employment opportunities? British Journal of Criminology, 4, 264-268.

Bovenkerk, F., Gras, M. \& Ramsoedh, D. (1994). Discrimination against migrant workers and ethnic minorities in access to employment in the Netherlands. International Migration Papers, 4. Geneve: International Labour Organisation (ILO). 
Buikhuisen, W. \& Dijksterhuis, F.P. (1969). Sollcitatiekansen van delinquenten. Nederlands Tijdschrift voor Criminologie, 11(1), 50-58.

Buikhuisen, W. \& Dijksterhuis, F.P. (1971). Delinquency and stigmatisation. British Journal of Criminology, 11(2), 185-187.

Bursell, M. (2014). The multiple burdens of foreign-named men. Evidence from a field experiment on gendered ethnic hiring discrimination in Sweden. European Sociological Review, 30(3), 99-109.

Bushway, S.D. (2004). Labor market effects of permitting employer access to criminal history records. Journal of Contemporary Criminal Justice, 20, 276-291.

Bushway, S.D., Stoll, M.A. \& Weiman, D.F. (2007). Barriers to re-entry? The labor market for released prisoners in Post-Industrial America. New York: Russel Sage Foundation.

Carlsson, M. (2010). Experimental evidence of discrimination in the hiring of first- and second-generation immigrants. Labour, 24(3), 263-278.

Carlsson, M. \& Rooth, D-O. (2007). Evidence of ethnic discrimination in the Swedish labor market using experimental data. Labour Economics, 14(4), 716-729.

Cediey, E. \& Foroni, F. (2008). Discrimination in access to employment on grounds of foreign origin in France. International Migration Papers, 85E. Geneve: International Labor Organisation (ILO).

Crutchfield, R.D. \& Pitchford, S.R. (1997). Work and crime: the effects of labor stratification. Social Forces, 76(1), 93-118.

Decker, S.H., Spohn, C., Ortiz, N.R. \& Hedberg, E. (2014). Criminal stigma, race, gender, and employment: an expanded assessment of the consequences of imprisonment for employement. www.ncjrs.gov/pdffiles1/nij/grants/244756.pdf.

Deliens, L. (1983). Ongelijke sociale distributie van de tewerkstellingskansen van ex-gedetineerden. Panopticon, 4(6), 530-541.

Dirkzwager, A., Blokland, A., Nannes, K. \& Vroonland, M. (2015). Effecten van detentie op het vinden van werk en woning. Tijdschrift voor Criminologie, 57(1), 5-30.

Dolfing, M. \& Tubergen, F. van (2005). Bensaïdi of Veenstra? Een experimenteel onderzoek naar discriminatie van Marokkanen in Nederland. Sociologie, 1(4), 407-422.

Duguet, E., Parquet, L. du, Horty, Y. l' \& Petit, P. (2015). New evidence of ethnic and gender discriminations in the French labor market using experimental data. A ranking extension of responses from correspondence tests. Annals of Economics and Statistics, 117-118, 21-39.

Freeman, R. (1999). The economics of crime. In O. Aschenfelter en D.Card (red.) Handbook of labor economics, pp.3529-3571. Amsterdam: Elsevier.

Gaddis, S.M. (2015). Discrimination in the credential society. An audit study of race and college selectivity in the labor market. Social Forces, 93(4), 1451-1479.

Galgano, S.W. (2009). Barriers to reintegration: an audit study of the impact of race and offender status on employment opportunities for women. Social Thought \& Research, 30(1), 21-37.

Geest, V.R. van der, Bijleveld, C.C.J.H. \& Blokland, A.A.J. (2011). The effects of employment on longitudinal trajectories of offending. A follow up in high-risk youth from ages 18 to 32. Criminology, 49(4), 1195-1234.

Holzer, H.J., Raphael, S. \& Stoll, M.A. (2004). Will employers hire ex-offenders? Employer perceptions, background checks, \& their determinants. In: M. Patillo-McCoy, D. Weiman \& B. Western (eds.). Imprisoning America: the social effects of mass incarceration. New York: Sage.

Jacquemet, N. \& Yannelis, C. (2012). Indiscriminate discrimination. A correspondence test for ethnic homophily in the Chicago labor market. Labour Economics, 19(6), 824-832. 
Jenkins, P. (1998). Moral panic. Changing concepts of the child molester in modern America. London: Yale University Press.

Kaas, L. \& Manger, C. (2012). Ethnic discrimination in Germany's labour market: a field experiment. German Economic Review, 13(1), 1-20.

KNAW (2013). Gedragscode voor gebruik van persoonsgegevens in wetenschappelijk onderzoek. Advies van de Sociaal-Wetenschappelijke Raad. Amsterdam: Koninklijke Nederlandse Akademie van Wetenschappen.

Lochner, L. (2004). Education, work and crime. A human capital approach. International Economic Review, 45, 811-843.

Luijkx, R. \& Wolbers, M.H.J. (2009). The effects of non-employment in early work-life on subsequent employment chances of individuals in the Netherlands. European Sociological Review, 25(6), 647-660.

McGinnity, F. \& Lunn, P. (2011). Measuring discrimination facing ethnic minority job applicants: an Irish experiment. Work, Employment \& Society, 25(4), 693-708.

Mesters, G., Geest, V.R. van der \& Bijleveld, C.C.J.H. (2015). Crime, employment and social welfare: an individual-level study on disadvantaged males. Journal of Quantitative Criminology. doi: 10.1007/210940.

Midtbøen, A.H. (2016). Discrimination of the second generation. Evidence from a field experiment in Norway. Journal of International Migration and Integration, 17(1), 253-272.

Oreopoulos, P. (2011). Why do skilled immigrants struggle in the labor market? A field experiment with thirteen thousand résumés. American Economic Journal: Economic Policy, 3, 148-171.

Osgood, D.W., Wilson J.K., Bachman, J.G., O’Malley, P.M. \& Johnston, L.D. (1996). Routine activities and individual deviant behavior. American Sociological Review, 61, 635-655.

Pager, D. (2003). The mark of a criminal record. American Journal of Sociology, 108, 937-975.

Pager, D. (2007). Marked: race, crime and finding work in an era of mass incarceration. Chicago, IL: University of Chicago Press.

Pager, D., Western, B. \& Bonikowski, B. (2009a). Discrimination in a low-wage labor market: a field experiment. American Sociological Review, 74(5), 777-799.

Pager, D., Western, B. \& Sugie, N. (2009b). Sequencing disadvantage: barriers to employment facing young black and white men with criminal records. The ANNALS of the American Academy of Political and Social Science, 623(1), 195-213.

Pickett, J.T., Mancini, C. \& Mears, D.P. (2013). Vulnerable victims, monstrous offenders, and unmanageable risk. Explaining public opinion on the social control of sex crime. Criminology, 51(3), 729-759.

Sampson, R.J. \& Laub, J.H. (1993). Crime in the making: pathways and turning points through life. Cambridge, MA: Harvard University Press.

Schwartz, R.D. \& Skolnick, J.H. (1962). Two studies of legal stigma. Social Problems, 10(2), 133-142.

Spence, M. (1973). Job market signaling. The Quarterly Journal of Economics, 87(3), 355-374.

Sutherland, E. \& Cressey, D. (1978). Principles of criminology. Philadelphia: J.B. Lippincott.

Uggen, C. (1999). Work as turning point in the life course of criminals. A duration model of age, employment, and recidivism. American Sociological Review, 67, 529-546.

Uggen, C. (2000). Work as a turning point in the life course of criminals. A duration model of age, employment, and recidivism. American Sociological Review, 65(4), 529-546. 
Uggen, C. \& Wakefield, S. (2008). What have we learned from longitudinal studies of work and crime? In: A.M. Liberman (ed.). The long view of crime. A synthesis of longitudinal research. New York: Springer, 198-240.

Uggen, C., Wakefield, S. \& Western. B. (2005). Work and family perspectives on reentry. In: J. Travis \& C. Visher (eds.). Prisoner reentry and crime in America. Cambridge, UK: Cambridge University Press, 209-243.

Wadsworth, T. (2006). The meaning of work. Conceptualizing the deterrent effect of employment on crime among young adults. Sociological Perspectives, 49, 343-368.

Zschirnt, E. \& Ruedin, D. (2016). Ethnic discrimination in hiring decisions: a meta-analysis of correspondence tests 1990-2015. Journal of Ethnic and Migration Studies, 42(7), 1115-1134.

\section{Appendix I}

C.V.

Naam:

Voornaam:

Geboortedatum: 01/04/1993

Geboorteplaats:

Amersfoort

Burgerlijke staat:

Samenwonend

Nationaliteit:

Nederlander

Rijbewijs:

B

Adres:

\section{Telefoon:}

E-mailadres:

.....@hotmail.com

\section{Opleidingen}

1997-2005: Basisschool

De Aloysiusschool Amersfoort

2005-2009: Diploma VMBO K Techniek Prisma College Amersfoort

2009-2011: Diploma Monteur Elektrotechniek ROC van Amsterdam

\section{Werkervaring}

2009-2011: Albert Heijn. Vakkenvuller: ik moest de vakken goed gevuld houden en vriendelijk zijn naar de klanten en hun vragen beantwoorden.

2011: Stage ..... bij ..... - door ..... erkend leerbedrijf 
2011-2013: ..... bij .....

\section{Certificaat}

\section{Vaardigheden}

Ik werk hard en ik werk goed in een team en ik ben leergierig.

\section{Programma's:}

\section{Hobby's}

Voetballen, uitgaan, films kijken, muziek

\section{Appendix II}

\section{Motivatiebrief}

$9 / 05 / 2013$

Geachte meneer/mevrouw,

Op ... heb ik de sollicitatie voor ... gevonden.

Ik woon nu nog in Amsterdam, maar over twee weken verhuis ik naar ... met mijn vriendin.

Ik wil graag bij u komen werken omdat ik het leuk werk vindt en graag als ... wil werken en omdat ik ervaring als ... heb. En ik ben een harde werker.

Een jaar geleden ben ik opgepakt voor een geweldsdelict. Ik heb toen een taakstraf opgelegd gekregen. Ik heb mijn straf daarvoor dus gehad, het was maar één keer en het gaat nu goed met mij. Bij mijn vorige sollicitatie ben ik in de problemen gekomen want toen ben ik pas later eerlijk geweest over mijn veroordeling. Daarom wil ik er nu graag meteen eerlijk over zijn.

Ik denk dat ik erg geschikt ben voor deze baan, ik hoop dat u mij zal uitnodigen voor een gesprek.

Dank u wel,

Vriendelijke groeten ... 